\title{
High-Level Comprehension Skill by using Competencies PISA in Indonesia's Education System
}

\author{
Sahyar \\ Department of Physics \\ Education, \\ State University of Medan, \\ Medan, \\ Wawan Bunawan \\ Department of Physics \\ Education, \\ State University of Medan, \\ Medan, Indonesia
}

\author{
Muhammad Aswin \\ Rangkuti \\ Department of Physics \\ Education, \\ State University of Medan, \\ Medan, Indonesia
}

\author{
Jeddah Yanti \\ Department of Physics, \\ State University of Medan \\ Medan, Indonesia
}

\begin{abstract}
The Programme for International Student Assessment (PISA) is an assessment of global competency in education that leads to adoption and development of sophisticated to equip next-generation for success in education and produce the world-renowned tech entrepreneurs. Asian countries dominate the top of the PISA rankings with the strongest performance than all regions in the OECD country. However, a reverse trend is observed in ASEAN middle-income countries because of disparities in access to basic education, particularly between rural and urban area, and also in teacher qualifications and quality of curricula. Indonesia is one of the countries facing this problem. The latest PISA report shows science education in Indonesian claims the $0.8 \%$ of share top performers in at least one subject, which science, literacy and math. Indonesia's average ranking across the three subjects is 69th out of 79 countries PISA. This score is lower than Singapore, 1st rank in applied PISA to education system in world. In consequent of the current curriculum system does not accustom students to works on a problem that can encourage, stimulate, and analyse a problem using high-level comprehension skill. So, these problems require further analysis by finding a solution to the problem involves constructing system, knowledge, and competencies that will transform the current curriculum to reach the aims of PISA.
\end{abstract}

Keywords-Curriculum standardization, knowledge and competencies PISA, PISA Indonesia

\section{INTRODUCTION}

Nowadays, the curriculum plays important role in the education system through processes or procedures that provide academic content such as a term, session, lesson period, etc. Curriculum, as a guideline in the implementation of teaching at all types of educational levels, exists to set the educational goals directed at achieving competencies [1]. By understanding the competencies, educators can choose and determine teaching methods, lessons, techniques, and media as well as appropriate teaching evaluation tools.

The current situation, the global index of economic openness trades for most ambitious countries competing to improve their educational, economic and technological systems that encourage competition and market innovation. As evidence of global index of economic openness, the impact of trade on poverty in developing countries over the last 10 years is improving by $8 \%$ over. 130 countries, representing $90 \%$ of the world's population, have risen since 2009. It shows that the change in the real income of the bottom $20 \%$ of the population is strongly correlated with the change in trade openness over the same period (Templeton World Charity Foundation, 2019). Countries with greater levels of Economic Openness are more productive. There are very strong links between education, productivity and economic growth. The benefits of more productive people mean more skills in needed higher levels of education [2]. This global issues in educational openness are covered by Program for International Student Assessment (PISA). PISA or the Program for International Student Assessment is a long-term development program to monitor the trending scientific news on hot topics and the latest discoveries in the world of natural science applied science [3].

PISA is classify based on the demographic scope of a country launched by the Organization for Economic Cooperation and Development (OECD) in 1997. Around 72 countries with 35 countries are categorized as part of the PISA founders and 37 as PISA partner countries. The most recent countries to become part of the OECD are Belgium, Chile, The Czech Republic, Estonia, Hungary, Mexico, Poland and Slovakia that stands for European countries. However, Asian countries lead the high PISA score than European countries since 2009 [4], [5], [6].

Over recent years, Asian countries dominate the top of the PISA rankings with the strongest performance than all regions in the OECD country [7]. OECD PISA survey on global education indicates the Asian countries consisting of China, Singapore, Taiwan, South Korea and Japan performed well in OECD's education assessment [8]. Since 2000, Indonesia, one of the partners OECD in Southeast Asia, is participating in the PISA assessment. PISA interventions in Asian countries have achieved outstanding results because it demonstrates the most influential PISA curriculum in the educational system which is relevant to context knowledge and expands application science [9]. The PISA system develops individuals, locally and globally on a personal, social and economic basis.

PISA curriculum system prepares students with a solid foundation in scientific knowledge and the scientific method and targets students to pursue their careers in revolutionizing and futuristic technology in fields such as education, medicine, forensics, aeronautics, and pharmaceutical research [10]. Building a strong foundation of basic scientific 
knowledge is required for high school student even they do not discuss and decide their future jobs. Students who attend school are also taught the scientific method to develop critical thinking to facing off the most concerning world issues.

Indonesia has been one of the PISA partner countries that have participated and applicated PISA since 2000. The foundation of the education system in Indonesia has been increasingly transformed to improve the wellbeing of citizens now and into the future. Over the period of 2012 to 2015, the application of the PISA system to 15-years-old students significantly affects the quality of student' academic performance in science. Basic scientific information and existing skills are a crucial role in those improvements. Approximately $60 \%$ of male correspondents generates better performance compared to $40 \%$ of female correspondents. This result has marked a significant improvement in the Indonesia education system. Indonesia is a country that has experienced a five-time improvement in the education system compared to 72 other countries. Indonesia creates a higher score of PISA in 2015 compared to Brazil. However, Indonesia still far behind Singapore, the first country in the 2015 PISA assessment score in the world. A country can lead the PISA ranking with research progress in the field of education that relies on the frequency of publications according to the journal, country, and scientific discipline [11].

PISA system refers to three types of educational competencies. The first competence is the ability to describe a bright background of natural phenomena, technical techniques and their implications for society. The second competency is to utilize the science and understanding of inquiry to identify questions (evaluation): can explain the scientific process of the products used: propose innovative and solutive steps in overcoming various types of scientific questions. The third competency is to interpret and evaluate data and scientific evidence and make conclusions that can be accounted for [12]. These three areas of competence mean scientific literacy at PISA 2015.

Previous studies find the considerable impact of PISA system on the scientific research from the areas of education and social sciences analysing student performance [13]. Countries that consistently rank top in the OECD International Student Assessment Program (PISA) usually publish their results in analysed journals and the number of articles related to this topic increases each year. Furthermore, these countries can support researchers to implement a large number of available results [14].

The aim of the PISA system in Indonesia is to produce talents for the younger generation with science acceleration and technology innovation. So, they can fulfil their encourage and potential to become independent producers. Hence, next generation can be applied their knowledge to various types of relevant science-based jobs.

\section{INDONESIA'S EDUCATION SYSTEM}

Since the beginning of the 21 Century, Indonesia's population has grown more than had been expected. The current population of Indonesia is 271,397,052 as of Sunday, October 6, 2019, based on the latest United Nations data. Indonesia population has rank 4 that is equal to $3.51 \%$ of the total world population. Historically, the population during the 1970s, 1980s, and 1990s shows a stalling of the fertility decline, which has proceeded steadily [15].

Historically, the population during the 1970s, 1980s, and 1990s shows a stalling of the fertility decline, which has proceeded steadily. However, the fertility declines experienced during the 1990s has not continued in the present century; fertility in 2012 was barely different from its level in 2002 and remained above replacement level (i.e. the level which, if continued into the future, will eventually lead to the population size remaining constant). For alleviating population pressures might be found in ensuring greater access to education.

The education system in Indonesia are required to attend nine years of school; consist of six-year primary school program and three-year junior secondary school, may be followed by three-year senior secondary school. Children's education in Indonesia is normally divided into two types, public school and private school. Public schools are administered and funded by the local, state or national government whereas private schools are funded wholly or partly by students' tuition and administered by a private body. At the same time, both of those types of school implement the 2013 curriculum (K-13) for their educational system [16].

According to Permendikbud Number 81A Year 2013, the national curriculum in Indonesia refers to the 2013 curriculum that highlights two types of competencies: Core Competencies and Basic Competencies [17]. Core competencies focus on the balancing spiritual and academic study, students' attitude (behavior), knowledge, and skills. Basic competencies concern on all knowledge and skills that must be taught in each subject at each level. The 2013 curriculum for elementary school is the thematic, integrative and junior and senior high school level (competencies are developed through: subjects); while the vocational level (competence is developed through: vocational). All courses are taught using a scientific approach which adopts 5 components: observing, asking questions, gathering information, reasoning, and communicating. 
(wit) WENR W Wonid Education

\section{EDUCATION IN INDONESIA}

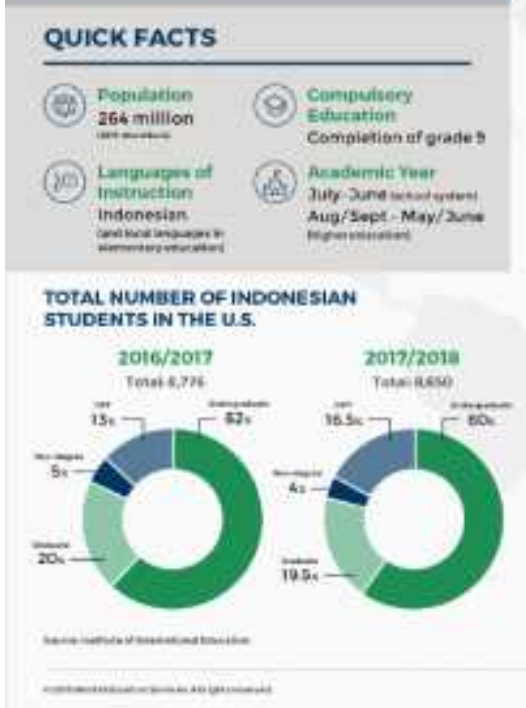

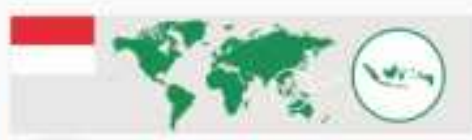

CRADINC SCALE \& WES CONVEASION

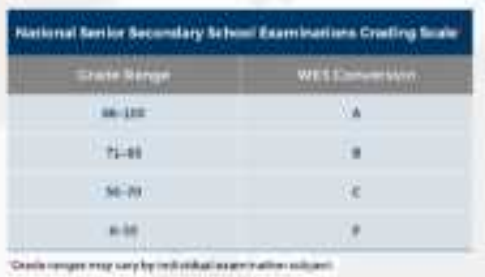

WES DOCUMENT HEQUIREMENTS

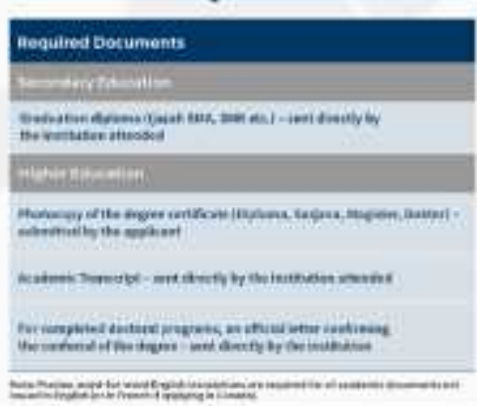

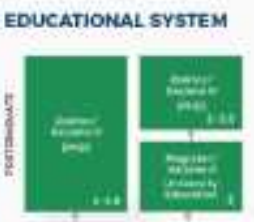
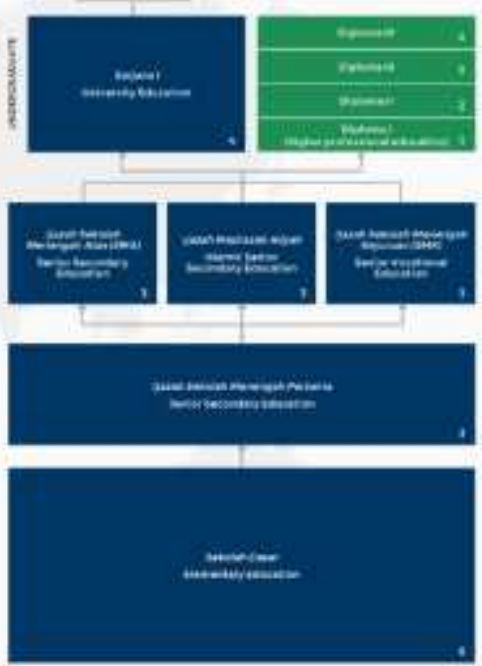

wenr.wes.org

Fig. 1. The recent education profile in Indonesian education system, student mobility, and an overview of the structure of the education system of Indonesia [18].

According to UNESCO, Indonesia's literacy rate is now high at around 95 percent, however, other educational indicators illustrate fallen well short of the 'internationally competitive' system; the quality of research and teaching in Indonesia's higher education system [19]. So, this phenomenon could lead to a major issue of the effectiveness of the 2013 curriculum implementation. The Programme for International Student Assessment (PISA) is known as an instrumental solution for measures of academic achievement of 15-year-old students in mathematics, science, and reading [20].

\section{RESULT AND DISCUSSION}

\subsection{SCIENCE LITERACY PISA 2015 IN INDONESIA}

Nowadays, education system in Indonesia adopts curriculum 2013, however, some content during the application on this curriculum may not be appropriate on the global development competition in educational circumstance (can be seen on Figure 1). We provide solutions to fulfil the requirements of global education, so-called PISA. The Programme for International Student Assessment (PISA) tests last conducted by the OECD in 2015 showed that Indonesian students were performing at lower levels in all areas - science, mathematics, and reading - than the OECD average. The scientific literacy PISA has been developed from 2006 to the latest in 2015 which consists of three competency standards, including (1) Explain scientific phenomena, (2) Evaluate and design scientific inquiry, and (3) Interpret scientific data and evidence and summarize the results of science [21] [22].
The overall PISA competency standard applies three types of knowledge:

1. Content knowledge includes factual knowledge and basic concepts of science and its guarantee the successful application. Factual knowledge is basic elements of scientific facts that occur in detail and systematically. Conceptual knowledge represents the idea or understanding of a scientific concept that is quoted from concrete (factual) events.

2. Procedural knowledge includes the concepts of independent variables, dependent variables and control variables, the concepts of quantitative and qualitative measurements (observation), scales, single and repeated measurements, the use of data repetition (graphs, tables, diagrams, variable setting strategies, designing experiments.

3. Epistemic knowledge includes topics about how to construct and see the most influential parts of science internally and the role of science externally. Indicator trends show the level of change in achievement and distribution of achievement, the relationship between student levels, school levels and the background of the system for each type of level and achievement results (epistemic knowledge).

Test Levels PISA contains questions representing seven levels of proficiency. Question Categories of PISA contains questions which provide different contexts and test different skills (can be seen Figure 2.) 

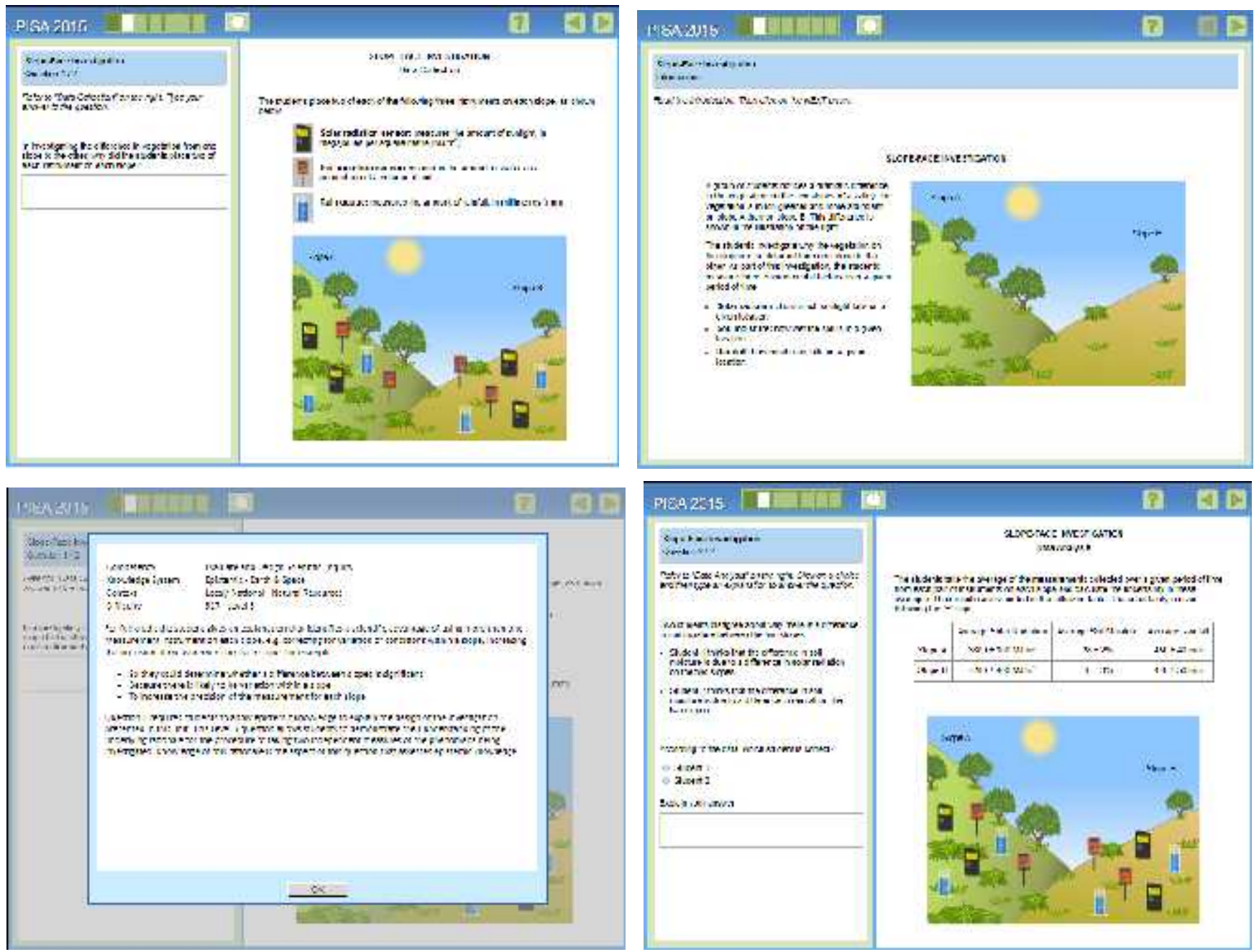

Fig. 2. Try out a selection of PISA 2015 science questions. Have a go at answering PISA 2015 questions to discover their level of difficulty and the concepts being tested.

\subsection{HIGH-LEVEL COMPREHENSION SKILL}

The Programme for International Student Assessment (PISA) tests for Indonesian students were performing at Highlevel understanding skills consist of six levels in the cognitive domain from lower to higher: knowledge, understanding, application, analysis, synthesis, and evaluation. High level skills are the ability to imagine and describe science as logic or knowledge [23]. High-level skills can be measured by success in scientific work applications. Maier et al. decide the high-level comprehension skill into some skill and competencies, include:

1. Balance of technical knowledge with interpersonal skills, including the ability to communicate technical information to non-scientific people. (29\%)

2. Command of the basics: write, communicate, summarize, and report, including the ability to maintain confidential material. $(18 \%)$

3. Genuine mastery of their discipline of study, allowing them to contribute educated opinions. (16\%)

4. Experience: have professional training which can include internships, cooperative education, research projects, and summer work engagements in professional settings before entering the workplace. (15\%)

5. Ability to adapt knowledge to different contexts. (14\%)

6. Diverse skills in problem solving and scientific method with a strong analytical mind. (14\%)

7. Ability to adapt to the professional business environment. $(12 \%)$

8. Having skills in several diverse science backgrounds. $(11 \%)$

9. A strong knowledge of technology, including the ability to use various computer programs. (11\%)

10. An ability to conduct field work. (7\%)

\section{CONCLUSIONS}

The implementation of PISA competencies in the Indonesian education system targets every high-school student to have high-level comprehension skill with a solid foundation in scientific knowledge and the scientific method. The highlevel comprehension skill is intending student to be independent and self-reliant. So, students find their definite effort to pursue their future careers in revolutionizing and futuristic technology in fields related to science and 
technology such as education, engineering, technician, dental, pharmaceutical, and etc

\section{ACKNOWLEDGMENT}

This research was supported by Ministry of Research, Technology and Higher Education of the Republic of Indonesia.

\section{REFERENCES}

[1] Zierer, K., 2013. What Is a Good School? Critical Thoughts About Curriculum Assessments. The Educational Forum, 77(3), 336-341. doi:10.1080/00131725.2013.792899

[2] Hopfenbeck, T. N., 2016. The power of PISA - limitations and possibilities for educational research. Assessment in Education: Principles, Policy \& Practice, 23(4), 423-426. doi:10.1080/0969594x.2016.1247518

[3] Keskin, H. K., 2014. Programme for International Student Assessment (PISA) Reading Competencies: A Study of the Factors in Academic Reading. The Anthropologist, 18(1), 171-181. doi:10.1080/09720073.2014.11891533

[4] Goldstein, H., 2004. International comparisons of student attainment: some issues arising from the PISA study. Assessment in Education: Principles, Policy \& Practice, 11(3), 319-330. doi:10.1080/0969594042000304618

[5] Grek, S., 2009. Governing by numbers: the PISA "effect" in Europe. Journal of Education Policy, 24(1), 23-37. doi:10.1080/02680930802412669

[6] Harju-Luukkainen, H., Vettenranta, J., Kanervio, P., \& Pulkkinen, S. 2014. Principals' Perceptions for Finnish- and Swedish-Language Schools in Finland: An Analysis of School-Level Indices from Programme for International Student Assessment 2009. Leadership and Policy in Schools, 13(3), 334-351. doi:10.1080/15700763.2014.922996

[7] Jerrim, J., 2015. Why do East Asian children perform so well in PISA? An investigation of Western-born children of East Asian descent. Oxford Review of Education, 41(3), 310-333. doi:10.1080/03054985.2015.1028525

[8] Deng, Z., \& Gopinathan, S., 2016. PISA and high-performing education systems: explaining Singapore's education success. Comparative Education, 52(4), 449-472. doi:10.1080/03050068.2016.1219535

[9] Waldow, F., Takayama, K., \& Sung, Y.-K., 2014. Rethinking the pattern of external policy referencing: media discourses over the "Asian Tigers" PISA success in Australia, Germany and South Korea. Comparative $\quad$ Education, 30(3), 302-321. doi:10.1080/03050068.2013.860704

[10] Tienken, C. H., 2017. Understanding PISA Results. Kappa Delta Pi Record, 53(1),6-8. doi:10.1080/00228958.2017.1264806
[11] Hopfenbeck, T. N., Lenkeit, J., El Masri, Y., Cantrell, K., Ryan, J., \& Baird, J.-A., 2017. Lessons Learned from PISA: A Systematic Review of Peer-Reviewed Articles on the Programme for International Student Assessment. Scandinavian Journal of Educational Research, 62(3), 333353. doi:10.1080/00313831.2016.1258726

[12] Aloisi, C., \& Tymms, P., 2017. PISA trends, social changes, and education reforms. Educational Research and Evaluation, 23(5-6), 180220. doi:10.1080/13803611.2017.1455290

[13] Domínguez, M., Vieira, M.-J., \& Vidal, J., 2012. The impact of the Programme for International Student Assessment on academic journals. Assessment in Education: Principles, Policy \& Practice, 19(4), 393-409. doi:10.1080/0969594x.2012.659175

[14] Baker, R., \& Jones, A., 2005. How can international studies such as the international mathematics and science study and the programme for international student assessment be used to inform practice, policy and future research in science education in New Zealand?. International Journal of Science Education, 27(2), 145-157. doi:10.1080/0950069042000276695

[15] Ministry Of Foreign Affairs of The Republic of Indonesia, 2019. Indonesia and Human Rights (published October 2019). https://kemlu.go.id/portal/en/read/97/halaman_list_lainnya/indonesiaand-human-rights

[16] UNESCO, 2011. World Data on Education 7th Edition. (publised 2011) http://www.ibe.unesco.org/sites/default/files/Indonesia.pdf

[17] Permendikbud Number 81A Year 2013, 2013. The guidline of curriculum implementation on learning. Jakarta: Minitry of Education and Culture of The Republic of Indonesia.

[18] Dilas, D. B., Christopher, M., Ying H., and Stefan T., Education in Indonesia, (published March 21, 2019) https://wenr.wes.org/2019/03/education-in-indonesia-2

[19] Harju-Luukkainen, H., Vettenranta, J., Ouakrim-Soivio, N., \& Bernelius, V., 2016. Differences between students' PISA reading literacy scores and grading for mother tongue and literature at school: A geostatistical analysis of the Finnish PISA 2009 data. Education Inquiry, 7(4), 29413. doi:10.3402/edui.v7.29413

[20] Cromley, J. G., 2009. Reading Achievement and Science Proficiency: International Comparisons from the Programme on International Student Assessment. Reading Psychology, 30(2), 89-118. doi:10.1080/02702710802274903

[21] Ertl, H., 2006. Educational standards and the changing discourse on education: the reception and consequences of the PISA study in Germany. Oxford Review of Education, 32(5), 619-634. doi:10.1080/03054980600976320

[22] Wu, H., Gao, X., \& Shen, J., 2019. Principal leadership effects on student achievement: a multilevel analysis using Programme for International Student Assessment 2015 data. Educational Studies, 1-21. doi:10.1080/03055698.2019.1584853

[23] Maier, P., Anna, B. and Geraldine, P., 2009. Study Skills for Science, Engineering and Technology Students. Pearson Longman: England. 